\title{
Reclassification of Chromobacterium iodinum (Davis) in a Redefined Genus Brevibacterium (Breed) as Brevibacterium iodinum nom.rev.; comb.nov.
}

\author{
By M. D. COLLINS, ${ }^{*}$ DOROTHY JONES, ${ }^{1}$ R. M. KEDDIE ${ }^{2}$ \\ AND P. H. A. SNEATH ${ }^{1}$ \\ ${ }^{1}$ Department of Microbiology, School of Medicine and School of Biological \\ Sciences, University of Leicester, Leicester LE1 $7 R H$ \\ ${ }^{2}$ Department of Microbiology, University of Reading, Reading RG1 $5 A Q$
}

(Received 6 March 1980)

Chromobacterium iodinum (Davis) differs to such an extent from the type species of Chromobacterium, Chr. violaceum (Bergonzini), that it cannot be retained in this genus. Chemical, morphological and numerical phenetic data indicate a close relationship between $\mathrm{Chr}$. iodinum and the species Brevibacterium linens (Wolff, Breed). It is suggested that Chr. iodinum be reclassified in a redefined genus Brevibacterium as B. iodinum (Davis) nom.rev.; comb.nov.

\section{INTRODUCTION}

The generic assignment of the bacteria named Chromobacterium iodinum (Davis, 1939) has always been controversial (Tobie, 1945; Gilman, 1953; Sneath, 1956, 1960; Steele, 1961; Gerber \& Lechevalier, 1964; Colwell et al., 1969). In the 8th edition of Bergey's Manual of Determinative Bacteriology the species is listed as incertae sedis (Sneath, 1974) and it does not appear in the Approved List of Bacterial Names (Skerman et al., 1980).

Chromobacterium iodinum was isolated from milk during a routine bacteriological examination (Davis, 1939), but the original source could have been water, soil, human or animal. Davis (1939) described the organisms as Gram-negative, non-sporing, non-motile rods and stated that the most distinctive feature was the production of dark purple crystals on the surface of colonies and in the adjacent medium. He also noted the similarity between the pigment and crystals of 'ordinary iodine'. Chemical investigations (Clemo \& McIlwain, 1938; Tobie, 1945; Clemo \& Daglish, 1950) showed that the pigment, named iodinin, was a phenazine derivative quite unrelated to violacein, the pigment component of Chromobacterium violaceum (Tobie, 1938, 1939). Phenazines and their derivatives were thought to be fairly uncommon and for this reason Tobie (1945) suggested that all bacteria producing these compounds should be included in the genus Pseudomonas. He therefore proposed the reclassification of Chr. iodinum as Pseudomonas iodina and later Pseudomonas iodinum (Tobie, 1939, 1945). However, phenazines and their derivatives have subsequently been shown to be present in a variety of Gram-negative and Gram-positive bacteria (Gerber \& Lechevalier, 1964; Lechevalier et al., 1971).

Later studies of Chr. iodinum (P. iodinum), notably those of Gilman (1953), Steele (1961) and Sneath $(1956,1960)$, indicated that the organism was a Gram-positive rod with a coryneform morphology. Gilman (1953), however, thought the species should be retained in the genus Pseudomonas, despite its Gram-positive staining reactions. Sneath (1960) 
suggested that it might well be classified in the genus Corynebacterium or in the genus Brevibacterium but did not pursue the matter further.

Colwell et al. (1969), as a result of a comprehensive study of three cultures named Pseudomonas iodinum, proposed that the bacteria be reclassified in the genus Arthrobacter, as Arthrobacter iodinum. However, in the numerical taxonomic study of Jones (1975), one strain of Chr. iodinum (labelled 'coryneform species' NCIB 8179) was recovered in the same cluster as strains of Brevibacterium linens and showed no close relationship to any of the other coryneform taxa investigated, including $A$. globiformis and several other strains of the genus Arthrobacter. Nevertheless, Jones (1975) stated that the recovery of $P$. iodinum in the same cluster as $B$. linens 'is not easily explained' because '... All attempts to demonstrate the presence of the $B$. linens carotenoid-like material failed. It is possible that it is a carotenoid-less mutant but it would additionally have had to develop the purple crystals of iodinin.' Further support for a relationship between the two species comes from the report that $C h r$. iodinum, like $B$. linens, has a directly cross-linked meso-diaminopimelic acidcontaining peptidoglycan (Fiedler et al., 1970; Schleifer \& Kandler, 1972), and that the guanine plus cytosine $(\mathrm{G}+\mathrm{C})$ content of the DNA is $63 \mathrm{~mol} \%$ (Colwell et al., 1969), similar to that of $B$. linens (Crombach, 1972; Yamada \& Komagata, 1970, 1972).

It is now recognized that the results of lipid analyses are of value in the taxonomy of the coryneform bacteria (Collins et al., 1977, 1979a, b, 1980a; Minnikin et al., 1978, 1979). The cellular morphology and lipid composition of Chr. iodinum were therefore investigated in an attempt to clarify its taxonomic position especially with regard to its apparent taxonomic relationship with $B$. linens.

\section{METHODS}

Strains. Brevibacterium linens strains ATCC 9172, ATCC 9174 and NCIB 8546 and Chromobacterium iodinum strains NCDO 613 and NCIB 8179 were obtained from the relevant culture collections.

Morphological examination. Colonial and cellular morphology were examined and Gram-stains were done as described by Cure \& Keddie (1973) and Jones (1975).

Cultivation. Cultures for lipid analyses were grown in shake flasks in nutrient broth no. 2 (Oxoid) supplemented with glucose $\left(2 \mathrm{mg} \mathrm{ml}^{-1}\right)$ for 2 to $3 \mathrm{~d}$ at $30^{\circ} \mathrm{C}$. Cultures were checked for purity at maximum growth, collected by centrifugation (6000 $\mathrm{g}$ for $10 \mathrm{~min}$ ), washed with distilled water and freeze-dried.

Analysis of fatty acid methyl esters. Dry organisms $(50 \mathrm{mg})$ were examined using the acid methanolysis and thin-layer chromatography (t.l.c.) procedure described by Minnikin et al. (1975). Fatty acid methyl esters were purified and examined by gas-liquid chromatography as previously described (Collins et al., $1980 b$ ).

Analysis of polar lipids. Free lipids were extracted from dry organisms $(50 \mathrm{mg})$ using a modification (Kates, 1972; Card, 1973; Minnikin et al., 1979) of the procedure of Bligh \& Dyer (1959). Polar lipid patterns were obtained by two-dimensional t.l.c. of lipid extracts using HPTLC Kieselgel $60 \mathrm{~F}_{254}$ (Merck Art. $5628)$ plates $(10 \times 10 \mathrm{~cm})$. Chromatograms were developed in the first dimension with chloroform $/ \mathrm{methanol} /$ water $(65: 25: 4$, by vol.), and in the second with chloroform/acetic acid/methanol/water $(80: 15: 12: 4$, by vol.) Spraying with $10 \%$ molybdophosphoric acid in ethanol followed by heating at $125^{\circ} \mathrm{C}$ for $15 \mathrm{~min}$ revealed the presence of all lipids. Specific spray reagents for lipid phosphate (Dittmer \& Lester, 1964), $\alpha$-glycols (periodate-Schiff) (Shaw, 1968), sugars ( $\alpha$-naphthol and anisaldehyde $\left./ \mathrm{H}_{2} \mathrm{SO}_{4}\right)(\mathrm{Jacin} \& \mathrm{Mishkin}$, 1965; Stahl \& Kaltenbach, 1961) and free amino groups (ninhydrin in water-saturated butanol) were also used.

Analysis of isoprenoid quinones. Isoprenoid quinones were extracted and purified as described by Collins et al. (1977) and were further examined by reverse phase partition chromatography using Merck RP-18 $\mathrm{F}_{\mathbf{2 5 4}}$ reverse phase thin-layer plates $(10 \times 10 \mathrm{~cm})$ and a polar developing mixture of acetone/water $(99: 1, \mathrm{v} / \mathrm{v})$ (Collins et al., 1980a). Mass spectra of the isoprenoid quinones were recorded on an AEI MS9 instrument using a direct insertion probe, an ionizing voltage of $70 \mathrm{eV}$ and a temperature range of 200 to $220^{\circ} \mathrm{C}$.

\section{RESULTS}

Phase contrast micrographs indicated that Chromobacterium iodinum exhibited a coryneform morphology and a rod/coccus cycle (see Fig. 3), similar to that described for Brevibacterium linens (see Cure \& Keddie, 1973). 


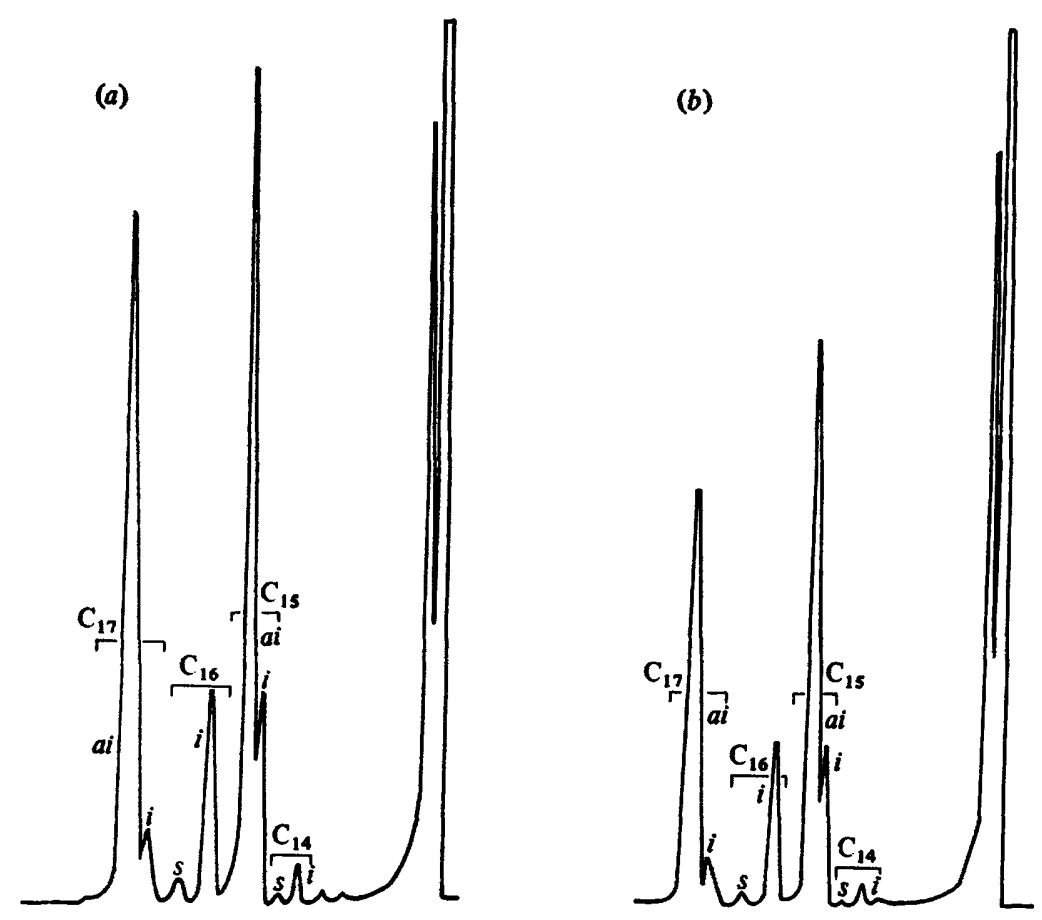

Fig. 1. Gas-liquid chromatographic analysis of representative fatty acid methyl esters of Chromobacterium iodinum $(a)$ and Brevibacterium linens $(b)$. The column $(6.5 \mathrm{~m})$ containing $7 \%$ ethyleneglycol adipate on 80 to 100 mesh Chromosorb G AW-DMCS was operated isothermally at $200^{\circ} \mathrm{C}$. Abbreviations: $i$, iso acid; ai, anteiso acid; $s$, straight-chain acid.

Whole-organism methanolysates of the test strains showed the presence on thin-layer chromatographs of single spots corresponding to non-hydroxylated fatty acid methyl esters (Goodfellow et al., 1976; Minnikin et al., 1978). All strains produced closely related fatty acid profiles; representative profiles are illustrated in Fig. 1 and quantitative data are shown in Table 1 . The fatty acids were composed primarily of anteiso- and iso-methylbranched acids (98.4 to $98.8 \%$ ) although straight-chain acids were also present in small amounts $(1.2$ to $1.6 \%)$. The major fatty acids in all strains were 14-methylhexadecanoic (anteiso $\mathrm{C}_{17}$ ) and 12-methyltetradecanoic (anteiso $\mathrm{C}_{13}$ ) acids (Table 1).

Strains possessed remarkably similar, characteristic polar lipid patterns, representatives of which are shown in Fig. 2. Diphosphatidylglycerol (DPG) and phosphatidylglycerol (PG) were readily identified in all the extracts by their chromatographic behaviour and staining properties. In addition, all strains produced a characteristic lipid which gave negative reactions to the lipid phosphorus and ninhydrin sprays but positive reactions to the periodate-Schiff and $\alpha$-naphthol reagents. These glycolipids $(G)$ gave a green coloration with the anisaldehyde $/ \mathrm{H}_{2} \mathrm{SO}_{4}$ reagent indicating that they may contain mannose residues. This possibility was supported by co-chromatography of the unidentified glycolipid with dimannosyl diacylglycerol from Corynebacterium aquaticum (Khuller \& Brennan, 1972; Minnikin et al., 1978).

No evidence was found for the presence of ubiquinones (coenzyme $Q$ ) in the extracts of any strains; components that co-chromatographed with vitamin $\mathrm{K}$ were the only isoprenoid quinones detected. Ultraviolet absorption spectra of the purified quinones showed absorption maxima at 242,248,260, 270 and $326 \mathrm{~nm}$, in accord with published data for menaquinones (Dunphy \& Brodie, 1971). The mass spectra of the menaquinone samples 
Table 1. Percentage fatty acid composition of test strains

Equivalent chain lengths

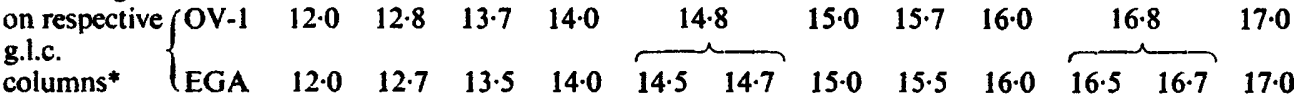

Assignment $\quad 12: 0$ ai-13 $\quad i-14 \quad 14: 0 \quad i-15$ ai-15 $\quad 15: 0 \quad i-16 \quad 16: 0 \quad i-17 \quad$ ai-17 $\quad 17: 0$

Brevibacterium

$\begin{array}{llllllllllllll}\text { linens ATCC } 9172 & \text { tr } & \text { tr } & 0.8 & 0.1 & 8.7 & 33.5 & \text { tr } & 11.5 & 1.1 & 4.3 & 40.0 & \text { tr }\end{array}$

Brevibacterium

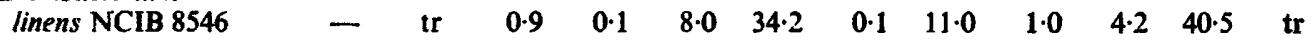

Brevibacterium

$\begin{array}{lllllllllllll}\text { linens ATCC } 9174 & - & \text { tr } & 0.8 & 0.2 & 8.0 & 32.9 & \text { tr } & 11.4 & 1.2 & 1.4 & 40.9 & 0.2\end{array}$

Chromobacterium

$\begin{array}{lllllllllllll}\text { iodinum NCDO } 613 & \text { tr } & 0.2 & 1.0 & 0.3 & 7.5 & 32.5 & \text { tr } & 9.7 & 1.3 & 4.3 & 43.2 & \text { tr }\end{array}$

Chromobacterium

iodinum NCIB 8179

tr, Trace amount.

* According to Miwa et al. (1960); EGA refers to ethyleneglycol adipate column.

$\dagger$ Abbreviations for fatty acids are explained by the following examples: 15:0 for the straight-chain pentadecanoic acid; $i-15$ for the iso acid 13-methyltetradecanoic acid; ai-15 for the anteiso acid 12-methyltetradecanoic acid.



(b)

Fig. 2. Two-dimensional thin-layer chromatograms of polar lipids from Chromobacterium iodinum (a) and Brevibacterium linens (b). Chloroform/methanol/water $(65: 24: 4$, by vol.) was used in the first dimension, and chloroform/acetic acid/methanol/water $(80: 15: 12: 4$, by vol.) was used in the second dimension. Abbreviations: DPG, diphosphatidylglycerol; PG, phosphatidylglycerol; G, glycolipid.

showed intense peaks at $\mathrm{m} / \mathrm{e} 187$ and 225 derived from the naphthoquinone nucleus, as expected from published data (Azerad \& Cyrot-Pelletier, 1973). Strong peaks corresponding to molecular ions $\left(\mathrm{M}^{+}\right)$were also observed. Details of the mass spectral analyses are shown in Table 2. Strains contained major amounts of dihydrogenated menaquinones with eight isoprene units [abbreviated as $\mathrm{MK}-8\left(\mathrm{H}_{2}\right)$ ], although small amounts of $\mathrm{MK}-8$ and $\mathrm{MK}-7\left(\mathrm{H}_{2}\right)$ were also detected in the mass spectra and on reverse phase partition chromotography. 
Table 2. Peaks corresponding to molecular ions in the mass spectra of menaquinones isolated from Brevibacterium linens and Chromobacterium iodinum

The main component of each series is denoted by +++ , any components greater than $50 \%$ of the main peak by ++ , and all other significant components by + .

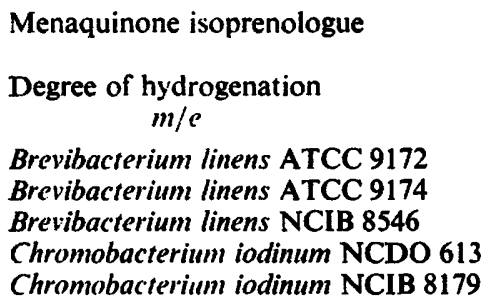

MK-7
$\left(\mathrm{H}_{2}\right)$
650
+
+
+
+
+

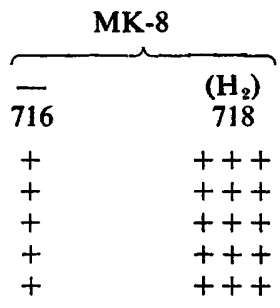

\section{DISCUSSION}

The recovery of menaquinones as the sole isoprenoid quinones from the Chr. iodinum strains confirms the views of several workers that this organism is Gram-positive (Gilman, 1953; Sneath, 1956, 1960; Jones, 1975; Weitzman \& Jones, 1975). The Gram-negative genera Chromobacterium and Pseudomonas contain ubiquinones (coenzyme Q) as their sole isoprenoid quinones (Bishop et al., 1962; Lester \& Crane, 1959; Page et al., 1960; Whistance et al., 1969).

The presence of $\mathrm{MK}-8\left(\mathrm{H}_{2}\right)$ as the major menaquinone isoprenologue in strains of $\mathrm{Chr}$. iodinum (Table 2) together with their coryneform morphology, fatty acid (Table 1) and polar lipid profiles (Fig. 2) support the results of numerical taxonomic (Jones, 1975), peptidoglycan (Fielder et al., 1970) and DNA base composition (Colwell et al., 1969; Yamada \& Komagata, 1970) studies, in indicating a taxonomic relationship between Chr. iodinum (Davis) and $B$. linens (Wolff) Breed. However, our results and those of Fielder et al. (1970) and Jones (1975) do not support the suggestion of Colwell et al. (1969) that Chr. iodinum should be reclassified in the genus Arthrobacter. Arthrobacter globiformis (the type species of the genus) and related species contain $\mathrm{MK}-\mathbf{9}\left(\mathrm{H}_{2}\right)$ as their major menaquinone isoprenologue (Yamada et al., 1976; Collins et al., 1979a) and diphosphatidylglycerol, phosphatidylglycerol and phosphatidylinositol as their major phospholipids, together with a complex mixture of glycolipids consisting of mono- and digalactosyl diacylglycerols and dimannosyl diacylglycerol (Kostiw et al., 1972; Minnikin et al., 1978). In addition, the peptidoglycan of $A$. globiformis and related species contains L-lysine (Fiedler et al., 1970; Schliefer \& Kandler, 1972).

On the basis of the results presented here and the results of the earlier numerical taxonomic (Jones, 1975), cell wall (Fiedler et al., 1970; Schleifer \& Kandler, 1972) and DNA base composition (Colwell et al., 1969; Yamada \& Komagata, 1970) studies, we consider that the bacteria now designated Chr. iodinum should be reclassified in the same genus as $B$. linens.

Brevibacterium linens is the type species of the genus Brevibacterium Breed 1953. This genus is presently considered to be incertae sedis, and therefore $B$. linens, the type species, is also so designated (Rogosa \& Keddie, 1974). However, there is much evidence that $B$. linens strains form a distinct group which could form the nucleus of a redefined genus Brevibacterium, as first suggested by Yamada \& Komagata (1972) and later by Jones (1975), Keddie \& Cure (1977) and Sharpe et al. (1978). We therefore consider that the bacteria now referred to as $B$. linens (Wolff) Breed and Chr. iodinum (Davis) should be classified as two separate species in a redefined genus Brevibacterium.

Chromobacterium iodinum differs from $B$. linens in the production of a characteristic phenazine derivative (iodinin) and also lacks the carotenoid characteristic of $\boldsymbol{B}$. linens 
Table 3. Some chemotaxonomic features of coryneform taxa

Data from Schleifer \& Kandler (1972), Minnikin et al. (1978), Keddie \& Jones (1980) and M. D. Collins (unpublished results).

\begin{tabular}{|c|c|c|c|c|c|c|}
\hline Taxon & $\begin{array}{l}\text { Major } \\
\text { wall } \\
\text { diamino } \\
\text { acid }\end{array}$ & $\begin{array}{c}\text { Mol } \\
0 \\
G \stackrel{0}{G}+C\end{array}$ & $\begin{array}{l}\text { Mycolic } \\
\text { acids }\end{array}$ & $\begin{array}{l}\text { Fatty acid } \\
\text { types* }\end{array}$ & $\begin{array}{l}\text { Major menaquinone } \\
\text { isoprenologue(s) }\end{array}$ & Polar lipids $\dagger$ \\
\hline $\begin{array}{l}\text { Arthrobacter } \\
\text { globiformis } \\
\text { group }\end{array}$ & L-Lysine & 59.66 & absent & $\mathbf{S}, \mathbf{A}, \mathbf{I}, \mathrm{U}$ & MK-9( $\left.\mathbf{H}_{2}\right)$ & $\begin{array}{l}\text { DPG, PG, PI, MGDG, } \\
\text { DGDG, DMDG }\end{array}$ \\
\hline $\begin{array}{l}\text { Arthrobacter } \\
\text { simplex }\end{array}$ & LL-DAP & $72-74$ & absent & $\mathbf{S}, \mathbf{A}, \mathbf{I}, \mathbf{U}, \mathbf{T}$ & MK-8(H, & DPG, PG, OH-PG \\
\hline $\begin{array}{l}\text { Brevihacterium } \\
\text { emend. }\end{array}$ & $\begin{array}{l}\text { meso- } \\
\text { DAP }\end{array}$ & $60-64$ & absent & $\mathbf{S}, \mathbf{A}, \mathbf{l}$ & MK- $8\left(\mathbf{H}_{2}\right)$ & DPG, PG, DMDG \\
\hline Caseobacter & $\begin{array}{l}\text { meso- } \\
\text { DAP }\end{array}$ & $60-67$ & present & S, U, T & MK-8( $\left.\mathbf{H}_{2}\right)$, MK- $-9\left(\mathbf{H}_{2}\right)$ & DPG, PI, PIDM \\
\hline Cellutomonas & $\begin{array}{l}\text { L-Orni- } \\
\text { thine }\end{array}$ & $71-73$ & absent & $\mathbf{S}, \mathbf{A}, \mathbf{I}$ & MK- $9\left(\mathbf{H}_{4}\right)$ & DPG, PI, PGL \\
\hline $\begin{array}{l}\text { Corynebacterium } \\
\text { sensu stricto }\end{array}$ & $n \begin{array}{l}m e s o- \\
\text { DAP }\end{array}$ & $51-59$ & present & $\mathbf{S}, \mathbf{U}$ & MK- $8\left(\mathrm{H}_{2}\right)$, MK- $9\left(\mathrm{H}_{2}\right)$ & DPG, PI, PIDM \\
\hline Curtobacterium & $\begin{array}{l}\text { D-Orni- } \\
\text { thine }\end{array}$ & 67.71 & absent & S, A, I & MK-9 & DPG, PG, G \\
\hline $\begin{array}{l}\text { Microhacterium } \\
\text { lacricum }\end{array}$ & L-Lysine & $69-70$ & absent & S, A, I & MK-10 MK-11, MK-12 & DPG, PG, DMDG \\
\hline
\end{tabular}

* S, Straight-chain acids; A, anteiso acids, I, iso acids; U, monounsaturated acids; T, tuberculostearic acid.

+ DPG, Diphosphatidylglycerol; PG, phosphatidylglycerol; PI, phosphatidylinositol; PIDM, phosphatidylinositol dimannosides; OH-PG, phosphatidylglycerol containing hydroxylated fatty acids; PGL, unknown phosphoglycolipids; G, unknown glycolipids; MGDG, monogalactosyl diacylglycerol; DGDG, digalactosyl diacylglycerol; DMDG, dimannosyl diacylglycerol.

(Jones, 1975). In addition, they can be differentiated on the basis of certain physiological tests (see species description). A problem arises because the name Chromobacterium iodinum (Davis) is not included in the Approved List of Bacterial Names (Skerman et al., 1980). Therefore we propose the revival of the species epithet 'iodinum' and at the same time the transfer of bacteria so designated to the genus Brevibacterium as Brevibacterium iodinum nom.rev.; comb.nov. (see Rules 28a and 41b; Lapage et al., 1975).

\section{Emended description of the genus Brevibacterium (Breed, 1953; Skerman et al., 1980) - Brevibacterium emend.}

The following description is based on the literature descriptions of Brevibacterium linens (Wolff) Breed and Chromobacterium iodinum (Davis) (Davis, 1939; Gilman, 1953; Sneath, 1956. 1960, 1974: Steele, 1961 ; Mulder et al., 1966; Colwell et al., 1969; Yamada \& Komagata, 1970; Fiedler et al., 1970; Crombach, 1972; Jones, 1975; Collins et al., 1977, $1979 a$; Keddie \& Jones, 1980; the present work).

The cells show a marked change of form during the growth cycle in complex media. Older cultures (about 3 to $7 \mathrm{~d}$ at $25^{\circ} \mathrm{C}$ ) are composed entirely or largely of coccoid cells which, on transfer to suitable fresh complex medium, grow out to give the slender irregular rods characteristic of exponential phase cultures. Many cells are arranged at an angle to each other to give V-formations; primary branching may occur. As growth proceeds, the rods become shorter and are eventually replaced by the coccoid cells (or short rods of occasional strains) characteristic of stationary phase cultures. Both rods and coccoid cells are Gram-positive, non-acid fast and non-motile; endospores are not formed. They are obligate aerobes, the mode of metabolism is respiratory, never fermentative; acids are not 
formed from glucose and other sugars in peptone media. They are catalase positive. The cell wall peptidoglycan is based on meso-diaminopimelic acid (variation Al $\gamma$ ); the cell walls do not contain arabinose. The bacteria contain dihydrogenated menaquinones with eight isoprene units, predominantly anteiso- and iso-methyl-branched fatty acids (anteiso $\mathrm{C}_{15}$ and anteiso $\mathrm{C}_{17}$ ) as major components, polar lipids comprising diphosphatidylglycerol, phosphatidylglycerol and dimannosyl diacylglycerol, but lack mycolic acids. The DNA base composition is in the range 60 to $64 \mathrm{~mol} \% \mathrm{G}+\mathrm{C}$.

The main distinguishing features between the genus Brevibacterium and other coryneform taxa are listed in Table 3 . The type species is $B$. linens.

\section{Emended description of Brevibacterium linens (Wolf) Breed}

This description is based mainly on studies of the type strain ATCC 9172 (Skerman et al., 1980) and strains ATCC 9174 and NCIB 8546 (Fiedler et al., 1970; Schliefer \& Kandler, 1972; Rogosa \& Keddie, 1974; Jones, 1975; Keddie \& Cure, 1977; Collins et al., $1979 a$; Keddie \& Jones, 1980; the present work).

Surface colonies on nutrient agar are small $(0.1$ to $0.2 \mathrm{~mm}$ diam.) after 1 to $2 \mathrm{~d}$, becoming larger $(2.5 \mathrm{~mm})$ on extended incubation; convex with entire margin, shiny; pale yellow to deep orange pigment produced. Pigment often produced only in the presence of light. Pigmented growth gives characteristic colour reactions with various acids and bases (Jones, 1975). Cultures on suitable media show the rod/coccus growth cycle and staining reactions described for the genus. Optimum growth temperature 20 to $25^{\circ} \mathrm{C}$; growth poor or absent at 5 and $37{ }^{\circ} \mathrm{C}$. Salt tolerant, grows in the presence of $\mathrm{NaCl}(10 \%, \mathrm{w} / \mathrm{v})$. Aerobic: mode of metabolism respiratory, never fermentative. Acids are not formed from glucose and other sugars in peptone media. Catalase positive, weakly oxidase positive. Gelatin liquefied, casein hydrolysed, hippurate hydrolysed, extracellular DNAase produced. The cell wall peptidoglycan contains meso-diaminopimelic acid (Fiedler et al., 1970); arabinose is not present but the wall polysaccharide contains a glycerol teichoic acid (Fiedler \& Stackebrandt, 1978). Mycolic acids are not present (Goodfellow et al., 1976). The principal isoprenoid quinones are dihydrogenated menaquinones with eight isoprene units. The fatty acid composition is mainly anteiso- and iso-methyl-branched acids with small amounts of straight-chain acids. The major fatty acids are 14-methylhexadecanoic (anteiso $\mathrm{C}_{17}$ ) and 12-methyltetradecanoic (anteiso $\mathrm{C}_{15}$ ) acids. The polar lipids comprise diphosphatidylglycerol, phosphatidylglycerol and dimannosyl diacylglycerol. The $\mathrm{G}+\mathrm{C}$ content of the DNA, determined by estimation of the melting point, is 60 to $64 \mathrm{~mol} \%$ (Yamada \& Komagata, 1970; Crombach, 1972; Bousfield, 1972).

\section{Description of Brevibacterium iodinum nom.rev.; comb.nov.}

This description is based on studies of strains NCDO 613, NCIB 8179, ATCC 15728, and ATCC 15729 (Clemo \& Daglish, 1950; Gilman, 1953; Sneath, 1956, 1960; Steele, 1961; Colwell et al., 1969: Fiedler et al., 1970; Jones, 1975; the present work).

Surface colonies on nutrient agar are 0.75 to $1 \mathrm{~mm}$ diam. after 1 to $2 \mathrm{~d}$, becoming larger ( 2 to $5 \mathrm{~mm}$ ) on extended incubation; convex with entire margin, shiny. Blue to purple extracellular crystals of iodinin visible within $2 \mathrm{~d}$ in areas of heavy growth. Iodinin production not influenced by light but better production on certain media (Colwell et al., 1969). Colour reactions typical of $B$. linens growth absent (Jones, 1975). Cultures on suitable media show the rod/coccus growth cycle and staining reactions described for the genus (Fig. 3). Gram-positive, but may appear Gram-negative (Jones, 1975). In very young cultures (about $8 \mathrm{~h}$ ) cells frequently stain one-half Gram-positive, the other Gramnegative (Colwell et al., 1969). Optimum growth temperature $25^{\circ} \mathrm{C}$; growth at $30^{\circ} \mathrm{C}$, but poor or absent at 5 and $37^{\circ} \mathrm{C}$. Aerobic: mode of metabolism respiratory. Acids not formed from glucose and other sugars in peptone media. Catalase positive, strongly oxidase 

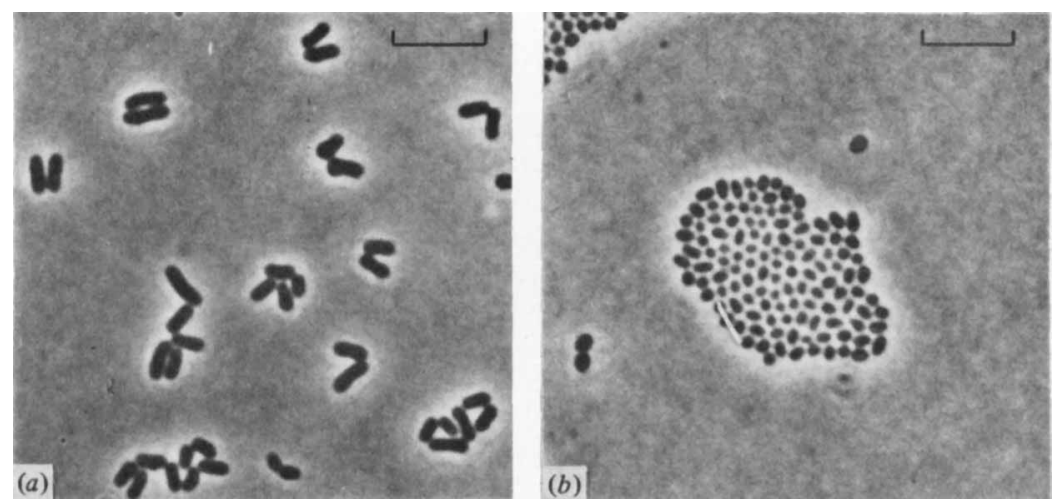

Fig. 3. Chromobacterium iodinum (NCIB 8179) grown in medium EYGA (Cure \& Keddie, 1973) at $25^{\circ} \mathrm{C}$ : $(a)$ after $6 \mathrm{~h} ;($ b) after $3 \mathrm{~d}$. Inoculum, coccoid cells from $7 \mathrm{~d}$ EYGA slope culture at 25 "C. Bar markers represent $5 \mu \mathrm{m}$.

positive. Gelatin hydrolysed, extracellular DNAase produced, weak hydrolysis of casein, hippurate not hydrolysed (Jones, 1975). The cell wall peptidoglycan contains meso-diaminopimelic acid (Fiedler et al., 1970). Mycolic acids are not present. The principal isoprenoid quinones are dihydrogenated menaquinones with eight isoprene units. The fatty acid composition is mainly anteiso- and iso-methyl-branched acids with small amounts of straight-chain acids. The major fatty acids are 14-methylhexadecanoic (anteiso $\mathrm{C}_{17}$ ) and 12-methyltetradecanoic (anteiso $\mathbf{C}_{15}$ ). Diphosphatidylglycerol, phosphatidylglycerol and dimannosyl diacylglycerol comprise the polar lipids. The $\mathrm{G}+\mathrm{C}$ content of the DNA, determined by estimation of the melting point is, $63 \mathrm{~mol} \mathrm{\%}$ (Colwell et al., 1969). The type strain is NCDO 613.

\section{REFER ENCES}

Azerad, R. \& Cyrot-Pelletier, M. L. (1973). Structure and configuration of the polyprenoid side chain of dihydromenaquinones from mycoand corynebacteria. Biochimie 55, 591-603.

Bishop, D. H. L., Pandya, K. P. \& KING, H. K. (1962). Ubiquinone and vitamin $K$ in bacteria. Biochemical Journal 83, 606-614.

BLIGH, E. G. \& DYER, W. J. (1959). A rapid method of total lipid extraction and purification. Canadian Journal of Biochemistry and Physiology 37, 911917.

Bousfiel.D, I. J. (1972). A taxonomic study of some coryneform bacteria. Journal of General Microbiology 71, 441-455.

BREED, R. S. (1953). The Brevibacteriaceae fam. nov. of order Eubacteriales. Riass Communicazione, $V I t h$ International Congress for Microbiology, Rome 1, 13-14.

CARD, G. L. (1973). Metabolism of phosphatidylglycerol, phosphatidylethanolamine and cardiolipin of Bacillus stearothermophilus. Journal of Bacteriology 114, 1125-1137.

Clemo, G. R. \& Daglish, A. F. (1950). The phenazine series. Part VIII. The constitution of the pigment of Chromobacterium iodinum. Journal of the Chemical Society, 1481-1485.
Clemo, G. R. \& Mcllwain, H. (1938). The phenazine series. Part VII. The pigment of Chromobacterium iodinum; the phenazines di- $N$-oxides. Journal of the Chemical Society, 479-483.

Collins, M. D., Pirouz, T., Goodfellow, M. \& Minnikin, D. E. (1977). Distribution of menaquinones in actinomycetes and corynebacteria. Journal of General Microbiology 100, 221-230.

Collins, M. D., Goodfellow, M. \& Minnikin, D. E. $(1979 a)$. Isoprenoid quinones in the classification of coryneform and related bacteria. Journal of General Microbiology 110, 127-136.

Collins, M. D., Jones, D., Goodfellow, M. \& MinNikin, D. E. (1979b). Isoprenoid quinone composition as a guide to the classification of Listeria, Brochothrix, Erysipelothrix and Caryophanon. Journal of General Microbiology 111, 453-457.

Collins, M. D., Shah, H. N. \& Minnikin, D. E. $(1980 a)$. A note on the separation of natural mixtures of bacterial menaquinones using reverse phase thin-layer chromatography. Journal of Applied Bacteriology 48, 277-282.

Collins, M. D., Goodfellow, M. \& Minnikin, D. E. $(1980 b)$. Fatty acid, isoprenoid quinone and polar lipid composition in the classification of 
Curtobacterium and related taxa. Journal of General Microbiology 118, 29-37.

Colwell, R. R., Citarella, R. V., Rmman, I. \& Chapman, G. B. (1969). Properties of Pseudomonas iodinum. Canadian Journal of Microbiclogy 15, 851-857.

Crombach, W. H. J. (1972). DNA base composition determination of soil arthrobacters and other coryneforms from cheese and sea fish. Antonie van Leeuwenhoek 38, 105-120.

Cure, G. L. \& KedDIE, R. M. (1973). Methods for the morphological examination of aerobic coryneform bacteria. In Sampling-Microbiological Monitoring of Environments, pp. 123-135. Edited by R. G. Board \& D. W. Lovelock. London: Academic Press.

DAvIs, J. G. (1939). Chromobacterium iodinum (n.sp.). Zentralblatt für Bakteriologie. Parasitenkunde, Infektionskrankheiten und Hygiene (Abteilung II) 100, 273-276.

DITTMER, J. C. F. \& Lester, R. L. (1964). A simple specific spray for the detection of phospholipids on thin-layer chromatograms. Journal of Lipid Research 5, 126-127.

DuNPhy, P. J. \& Brodie, A. F. (1971). The structure and function of quinones in respiratory metabolism. Methods in Enzymology 18, 407-461.

Fiedler, F., Schlleifer, K. H., CzHHARZ, B., INTERSCHICK, E. \& KANDLER, O. (1970). Murein types in arthrobacter, brevibacteria, corynebacteria and microbacteria. Publicaticins de la Faculté des sciences de l'Université J. E. Purkyne, Brno 47, 111-122.

Fiedler, F. \& Stackebrandt, E. (1978). Taxonomical studies on Brevibacterium linens. $A b$ stracts of the XIIth International Congress of Microbiology, Munich, C45, p. 96.

Gerber, N. N. \& LeCheValier, M. P. (1964). Phenazines and phenoxazinones from Waksmania aerata sp.nov, and Pseudomonas iodina. Biochemistry 3, 598-602.

Gilman, J. P. (1953). Studies on certain species of bacteria assigned to the genus Chromobacterium. Journal of Bacteriology 65, 48-52.

Goodfellow, M., Collins, M. D. \& Minnikin, D. E. (1976). Thin-layer chromatographic analysis of mycolic acid and other long-chain components in whole-organism methanolysates of coryneform and related taxa. Journal of General Microbiology 96, 351-358.

JACIN, H. \& Mishkin, A..R. (1965). Separation of carbohydrates on borate-impregnated silica gel $\mathbf{G}$ plates. Journal of Chromatography 18, 170-173.

JONES, D. (1975). A numerical taxonomic study of coryneform and related bacteria. Journal of General Microbiology 87, 52-96.

Kates, M. (1972). Techniques of Lipidology. Amsterdam: North Holland Publishing Co.

KEDDIE, R. M. \& CURE, G. L. (1977). The cell wall composition and distribution of free mycolic acids in named strains of coryneform bacteria and in isolates from various natural sources. Journal of Applied Bacteriology 42, 229-252.

KEDDIE, R. M. \& JONEs, D. (1980). Saprophytic aerobic coryneform bacteria. In The Prokaryotes: Handbook on Habitats, Isolation and Identification of Bacteria. Edited by M. P. Starr, H. Stolp, H. G. Trüper, A. Balows \& H. G. Schlegel. New York: Springer-Verlag (in the Press).

Khuller, G. K. \& BrennaN, P. J. (1972). Further studies on the lipids of corynebacteria. The mannolipids of Corynebacterium aquaticum. Biochemical Journal 127, 369-373.

Kostiw, L. L., BoyleN, C. W. \& Tyson, B. J. (1972). Lipid composition of growing and starving cells of Arthrobacter crystallopoietes. Journal of Bacteriology 111, 103-111.

Lapage, S. P., Sneath, P. H. A., Lessel, E. F., Skerman, V. B. D., Seeliger, H. P. R. \& Clark, W. A. (editors) (1975). International Code of Nomenclature of Bacteria. Washington: American Society for Microbiology.

LeChevalier, H. A., LeCheVAlieR, M. P. \& GeRBer, N. N. (1971). Chemical composition as criterion in the classification of actinomycetes. Advances in Applied Microbiology 14, 47-57.

Lester, R. L. \& CRANe, F. L. (1959). The natural occurrence of Coenzyme $Q$ and related compounds. Journal of Biological Chemistry 234, 2169-2175.

Minnikin, D. E., Alshamaony, L. \& Goodfellow, M. (1975). Differentiation of Mycobacterium, Nocardia and related taxa by thin-layer chromatographic analysis of whole-organism methanolysates. Journal of General Microbiology 88, 100-104.

Minnikin, D. E., Goodfellow, M. \& Collins, M. D. (1978). Lipid composition in the classification and identification of coryneform and related taxa. In Coryneform Bacteria, pp. 85-160. Edited by I. J. Bousfield \& A. G. Callely, London: Academic Press.

Minnikin, D. E., Collins, M. D. \& Goodfellow, M. (1979). Fatty acid and polar lipid composition in the classification of Cellulomonas, Oerskovia and related taxa. Journal of Applied Bacteriology 47, 87-95.

Miwa, T. K., Mikolajczak, K. L., Earle, F. R. \& Wolff, I. A. (1960). Gas chromatographic characterization of fatty acids. Analytical Chemistry 32, 1739-1742.

Mulder, E. G., Adamse, A. D., Antheunisse, J., DEINEMA, M. H., WOLDENDORP, J. W. \& ZEVENHUizen, L. P. T. M. (1966). The relationship between Brevibacterium linens and bacteria of the genus Arthrobacter. Journal of Applied Bacteriology 29, 44-71.

Page, A. C., Gale, P., Wallick, J., Walton, R. B., MCDANIEl, L. E., WoOdRufF, H. B. \& Folkers, K. (1960). Coenzyme Q. XVIII. Isolation of Coenzyme $\mathbf{Q}$ from bacterial fermentations. Archives of Biochemistry and Biophysics 89, 318321.

Rogosa, M. \& Keddie, R. M. (1974). Genus Brevibacterium. In Bergey's Manual of Determinative Bacteriology, 8th edn, pp. 625-628. Edited by R. E. Buchanan \& N. E. Gibbons. Baltimore: Williams \& Wilkins.

Schleifer, K. H. \& Kandler, O. (1972). Peptidoglycan types of bacterial cell walls and their taxonomic implications. Bacteriological Reviews 36, 407-477. 
Sharpe, M. E., Law, B. A., Phillips, B. A. \& PITCher, D. G. (1978). Coryneform bacteria producing methanethiol. In Coryneform Bacteria, pp. 289-300. Edited by I. J. Bousfield \& A. G. Callely. London: Academic Press.

SHAw, N. (1968). The detection of lipids on thinlayer chromatograms with the periodate-Schiff reagent. Biochimica et biophysica acta 164, 435436.

Skerman, V. B. D., McGowan, V. \& Sneath, P. H. A. (1980). Approved Lists of Bacterial Names. International Journal of Systematic Bacteriology 30, 225-420.

SNeATH, P. H. A. (1956). Cultural and biochemical characteristics of the genus Chromobacterium. Journal of General Microbiology 15, 70-98.

SNEATH, P. H. A. (1960). A study of the genus Chromobacterium. Iowa State Journal of Science 34, 243-500.

SNeAth, P. H. A. (1974). Genus Chromobacterium Bergonzini 1881. In Bergey's Manual of Determinative Bacteriolcgy, 8th edn, pp. 354-357. Edited by R. E. Buchanan \& N. E. Gibbons. Baltimore: Williams \& Wilkins.

Stahl, E. \& Kaltenbach, U. (1961). Dünnschicht Chromatographie. VI Mitteilung. Spurenanalyse von Zuckergemischen auf Kieselgur G-Schichten. Journal of Chromatography 5, 351-355.

Steele, K. J. (1961). The oxidase reaction as a taxonomic tool. Journal of General Microbiology 25, 297-306.

TOBIE, W. C. (1938). The pigment of Bacillus violaceus. III. The apparent relation of violacein to indigo. Journal of Bacteriology 35, 11-12.

TOBIE, W. C. (1939). The pigment of Bacillus violaceus. IV. The nature of the violacein molecule and factors affecting its stability. Bulletin de l'Association des diplomés de microbiologie de la Faculté de pharmacie de Nancy 18, 7-19.

TOBIE, W. C. (1945). A proposed biochemical basis for the genus Pseudomonas. Journal of Bacteriology 49, 459-462.

Weitzman, P. D. J. \& Jones, D. (1975). The mode of regulation of bacterial citrate synthase as a taxonomic tool. Journal of General Microbiology 89, 187-190.

Whistance, G. R., Dillon, J. F. \& Threlfall, D. R. (1969). The nature, intergeneric distribution and biosynthesis of isoprenoid quinones and phenols in Gram-negative bacteria. Biochemical Journal 111, 461-472.

Yamada, K. \& Komagata, K. (1970). Taxonomic studies on coryneform bacteria. III. DNA base composition of coryneform bacteria. Journal of General and Applied Microbiology 16, 215-224.

YamadA, K. \& Komagata, K. (1972). Taxonomic studies of coryneform bacteria. V. Classification of coryneform bacteria. Journal of General and Applied Microbiology 18, 417-431.

YAMADA, Y., INOUYe, G., TAHARA, Y. \& Kondo, K. (1976). The menaquinone system in the classification of coryneform and nocardioform bacteria and related organisms. Journal of General and Applied Microbiology 22, 203-214. 